DOI: https://doi.org/10.32839/2304-5809/2020-12-88-16

удК $81 ’ 37$

Павличко О.О., Мартинів О.М., Глюдз М.М.

Київський національний університет імені Тараса Шевченка

\title{
ПРЕЦЕДЕНТНА МОТИВАЦІЯ ФРАЗЕОЛОГІЧНИХ ОДИНИЦЬ НІМЕЦЬКОЇ МОВИ
}

Анотація. У науковій розвідці, з огляду на одну із актуальних проблем сучасної теорії номінації - дослідження мотиваційних механізмів, що проявляють себе на когнітивному та вербальному рівні, розглянуто питання прецедентних френоменів, які широко використовуються у процесах номінації та можуть слугувати мотиваторами фразеологічних одиниць. У статті проаналізовано сутність поняття прецедентних френоменів та їх типологію. Обгрунтовано диференціацію пецедентних феноменів за розмежуванням рівнів. У розвідці виявляються та аналізуються різні за інформативною насиченістю прецедентні мотиватори фрразеологізмів німецької мови, а також виокремлюються можливі типи мотивації за параметром мотиватора у структурі знань про позначене. У фразеологічному складі німецької мови серед прецедентних френоменів, які слугують мотиваторами фрразеологізмів виявлено прецедентні імена, що є персонажами релігійних та міфологічних сюжетів, топонімами з літературних, міфологічних та релігійних сюжетів, а також назви народів, племен, національностей, грошових одиниць, продуктів харчування. Мотиваторами фрразеологізмів можуть бути німецькі національні імена та імена відомих особистостей. Актуалізація прецедентного тексту, прецедентні висловлення, які ми розуміємо як пряме та квазіцитування, слугують мотиваторами сталих зворотів.

Ключові слова: прецедентні феномени, прецедентні імена, прецедентні тексти, прецедентні висловлення, мотиватор, пряме цитування, квазіцитування, фрразеологізми.

Pavlychko Oksana, Martyniv Oksana, Glyudz Myroslava Taras Shevchenko National University of Kyiv

\section{THE PRECEDENT MOTIVATION OF PHRASEOLOGICAL UNITS IN THE GERMAN LANGUAGE}

Summary. In the scientific research, one of the current problems of modern nomination theory - the study of motivational mechanisms which present themselves on the cognitive and verbal level, the question of precedent phenomena is shown which are widely used in the nomination processes and can be served as the motivators of phraseological units. The concept of precedent phenomena and their typology are analyzed in the article. The differentiation of pecedent phenomena by the level delimitation is substantiated. In the research the pecedent motivators of phraseological units in the German language are identified and analyzed by their different informative saturation, as well as the possible types of motivation are identified by the parameter of the motivator in the structure of knowledge about a certain thing. The precedent phenomena are the components of the conceptual system. In the cognitive aspect precedent motivators always have a certain structure of knowledge, the fragments of which correlate with its components. The precedent motivation of the phraseological units in accordance with the parameter of the status of the motivator of a particular component of the structure of knowledge about a certain item can be qualified in our research as propositional, associative, terminal and modus, as well as it can be based on the mythological nature of the phenomena. If the precedent motivator in the onomasiological structure of the phraseological units uses the motivational symbols in the direct meanings from predicative and argumentative structures and different levels of the nuclear component of the structure, then such kind of motivation is qualified as the propositional one. The precedent motivators can correlate with the associative and terminal part of the structure of knowledge about a certain item, which is based on the usage of symbols of one conceptual system to denote another one. The modus type of the precedent motivation applies to almost all its types, because the assessment is considered to be the universal linguistic category, which is mainly put in the meaning of the phraseological units. A very large number of precedent and motivated phraseological units are also based on the mythological nature, which forms the norms and values of the ethnic society and is a powerful regulator of the process of cultural and ethnic identification. In the phraseological structure of the German language among the precedent phenomena which are served as the motivators of phraseological units the precedent names are found which belong to the characters of religious and mythological plots, toponyms from literature, mythological and religious plots, the names of peoples, tribes, nationalities, monetary and food units. The German national names and the names of famous people can be the motivators of phraseological units. The actualization of the precedent text, as well as the precedent expressions we understand as the direct quotation and quasi-quotation. They can also be served as the motivators of set expressions.

Keywords: precedent phenomena, precedent names, precedent texts, precedent expressions, motivator, direct citation, quasi-quotation, phraseological units.

Постановка проблеми. 3 огляду на домінування в сучасних лінгвістичних розвідках когнітивно-дискурсивної наукової парадигми, дослідження співвідношення мови та свідомості отримує новий аспект висвітлення, який грунтуеться на врахуванні взаємодії індивідуальної та колективної сорери останньої за умови їхнього зв'язку з етнічністю та культурою. Особливості національної мовної свідомості проявляються у виборі національних прецедентних феноменів, національних стереотипів, у фррейм-структурах та в асоціаціях, які виникають у представників національно-лінгвокультурних суспільств в процесі комунікації. 
Прецедентні френомени належать до основних ядерних елементів когнітивної бази членів лінгвокультурного суспільства, яка є певним чином структурованою сукупністю знань та національно зумовлених уявлень. Без цього фонду знань та уявлень адекватна комунікація є практично неможливою.

На вербальному рівні такі концептуальні структури можуть мати репрезентацію словом, сполукою слів, висловленням предикативної природи, текстовим фррагментом і цілісним текстом. Відповідно, вони відображають здатність носіїв певної етнічної культури впізнавати в мові та мовленні важливі норми та цінності, культурні коди, разом з тим організовувати свою комунікацію відповідно до них.

Загальновідомо, що прецедентні френомени $є$ доволі активними в процесах номінації, які розглядаються сьогодні у когнітивному висвітленні. Безсумнівно, що й аналіз мотивації номінативних одиниць може здійснюватися за параметром прецедентності. Один із типів нового трактування мотиваційних відношень, який запропонувала О. О. Селіванова, базується на прецедентності / непрецедентності індрормаціі та характеризується вибором мотиваторів, позначення та зміст яких добре відомі представникам певного етнокультурного суспільства, що є актуальними в когнітивному і комунікативному плані. Аналіз прецедентних френоменів як компонентів етносвідомості дає можливість збільшити наші знання про іï особливості, з'ясувати статус i фрункціональну природу таких френоменів, а також поглибити уявлення про зв'язок номінації та когніції, спеціфріку організації знань в концептуальній системі.

Аналіз останніх досліджень і публікацій. Поняття прецедентності, прецедентного френомена не отримало в науковій літературі однозначного тлумачення та залишилося остаточно невизначеним, оскільки в процесі дослідження прецедентних френоменів виникли різні підходи щодо їх інтерпретації, про що свідчить велика кількість понять та термінів, як наприклад, поняття «прецедентного тексту» (Ю. М. Караулов, В. Г. Костомаров, Ю. О. Сорокін, Ю. Є. Прохоров), «прецедентного висловлення» (В. Г. Костомаров, В. В. Красних, «прецедентної ситуації», «прецедентного імені» (Д. Б. Гудков, І. В. Захаренко, В. В. Красних). О. О. Селівановою прецедентний феномен трактується як компонент знань, який $\epsilon$ актуальним та використаним у когнітивному й комунікативному плані, позначення та зміст якого добре відомі представникам певної етнокультурної спільноти [5]. Таке визначення поняття прецедентного феномену грунтуеться на дослідженнях Ю. М. Караулова, Д. Б. Гудкова, В. В. Красних. Модифрікуючи визначення В. М. Караулова, російська дослідниця В. В. Красних до числа прецедентних феноменів відносить такі типи: соціумно-прецедентний, національно-прецедентний та універсальнопрецедентний. Як зазначає авторка, соціумнопрецедентні френомени, які відомі будь-якому представнику того чи іншого соціуму (соціального, конфресійного, профресійного), входять в колективний когнітивний простір. Національно-прецедентні феномени є відомими для будь-якого представника того чи іншого національно-лінгво-культурного суспільства, адже належать до національної когнітивної бази. Останній тип прецедентних френоменів - універсально прецедентний, має гіпотетичний характер, оскільки міститься в універсальній когнітивний базі, для ствердження або заперечення якої потрібні глибокі дослідження [3, с. 50-51]. Зважаючи на наявний в лінгвістиці поділ прецедентних феноменів на типи (ім'я, текст, висловлення та ситуацію), суперечливим $€$ розгляд їхньої природи. Навряд чи можна повністю погодитися з думкою дослідників, щодо такої класифікації, оскільки вона побудована не за єдиним параметром. Як цілком слушно зауважуе українська лінгвістка О. О. Селіванова, диференціація прецедентних феноменів потребує насамперед розмежування рівнів, на яких вони визначаються. Дослідниця пропонуе розрізняти редеренційний рівень, на якому прецедентність представлена ситуацією чи сукупністю ситуацій. Тип такої ситуації має різну природу. Лінгвістка вважає, якщо подія відбулася в дійсності, вона $є$ реальною прецедентною ситуацією, якщо ж подія є вигаданою, їі потрібно кваліфікувати як змодельовану колективною чи індивідуальною свідомістю. В результаті, прецедентна ситуація $є$ раціональною або міфрологізованою. На когнітивному рівні прецедентність існуе у вигляді концептуальної структури інтеріоризованої ситуащії, на мовному рівні такі прецедентні структури можуть бути репрезентовані словом, сполукою, висловленням, текстом та текстовим фррагментом [4, с. 110].

Крім того, інший бік проблеми прецедентних феноменів вбачають у їхній вербалізації. Адже дослідники поділяють ї на вербальні та вербалізовані. До вербальних відносять прецедентне ім'я та прецедентне висловлювання, а до вербалізованих, на їх думку, можна зарахувати прецедентний текст та прецедентну ситуацію, які зберігаються у когнітивній базі, і при потребі можуть вербалізуватися [3, с. 49]. Певні сумніви виникають щодо такого розуміння вербалізації прецедентних феноменів. На нашу думку, до вербалізованих прецедентних феноменів можна віднести ім'я та висловлення, оскільки за ними на когнітивному рівні існуе прецедентна концептуальна структура, яка відповідає тій прецедентній ситуації, що сорормована свідомістю автора. Наприклад, компоненти фрразеологізмів, які є прецедентними іменами (Lazarus, Hiob, Achiles, Napoleon, Juda, Mohikaner, Amor чи висловлювання "Auch du, mein Sohn Brutus?», "Das war kein Heldenstück, Oktavio!» імплікують прецедентні ситуації. Крім того вважаємо, що прецедентні феномени можуть бути і невербальними. До них відносимо твори живопису, архітектури та музики.

Виділення невирішених раніше частин загальної проблеми. У виникненні та фрункціонуванні прецедентних френоменів можна виокремити два етапи. Перший - це процес виникнення прецедентного френомена, закріплення його в слові, сполуці, висловленні, яке має предикативну природу, в тексті та текстовому фррагменті. Інший етап визначають як фрразеологізацію прецедентного френомена, інакше кажучи, прецедентний феномен може слугувати мотиватором у процесі творення фрразеологізмів. 
Проблема вивчення мотиваційних механізмів номінативних одиниць, фрразеологізмів зокрема, $е$ актуальною на сучасному етапі розвитку лінгвістичної науки. Прецедентні френомени як мотиватори фрразеологічних одиниць німецької мови ще не були об'ектом когнітивно-ономасіологічних досліджень та потребують особливої уваги сучасних дослідників.

Формулювання цілей статті. Виявити та проаналізувати різні за інформативною насиченістю прецедентні мотиватори фрразеологізмів німецької мови, а також виокремити всі можливі типи мотивації за параметром відповідності мотиватора у структурі знань про позначене.

Виклад основного матеріалу. У процесі творення фрразеологічних одиниць німецької мови прецедентні феномени слугують мотиваторами, серед яких ми виокремлюемо прецедентні тексти, прецедентні ілена та прецедентні висловлення.

Питання прецедентного тексту вважають одним із дискусійних в лінгвістичній науці, оскільки він належить до найскладнішого виду прецедентних фоеноменів. Основні характеристики прецедентного тексту були розроблені Ю. М. Карауловим та знайшли надалі своє продовження в працях Ю. О. Сорокіна, Ю. Є. Прохорова, В. Г. Костомарова, Г. Г. Слишкіна та інших лінгвістів. До основних ознак прецедентного тексту Ю. М. Караулов відносить їх актуальність для особистості в когнітивному (пізнавальному та емоційному) відношенні, відомість широкому загалу, а також повторне звернення до тексту в дискурсі мовної особистості [1, с. 216]. Як зазначає автор, особливістю кожного прецедентного тексту є те, що він виступає цілісною одиницею позначення, знаком, який апелюе до тексту-джерела та представляе його за принципом «частина - ціле». Науковець розширюе розуміння прецедентного тексту, включивши в його склад лексеми, фрразеологізми та речення. На думку Н. Ю. Караулова, до прецедентних текстів не слід відносити наукові роботи чи газетні фейлетони, оскільки не всі представники соціуму їх читають. Однак не лише художня література слугує джерельною базою прецедентних текстів. Вони можуть існувати і у формі міфрів, легенд, казок та усно-поетичних творів. Корпус прецедентних текстів повинен стати частиною спільних знань і спільної культурної пам'яті, впізнаватися носіями мови та активувати вагомі для них концепти та їх зміст. Загалом корпус джерел прецедентних текстів $є$ великий, однак важливим джерелом прецендентних феноменів залишається Біблія.

У фрразеологічному складі німецької мови серед прецедентних френоменів виявлено прецедентні імена, які слугують мотиваторами фразеологізмів німецької мови та є персонажами релігійних сюжетів: Adam, Eva (einen neuen Adam anziehen - seine alten Gewohnheiten ablegen, ein neuer Mensch werden; seit Adam und Eva - seit je, solange man denken kann); Abraham (wie in Abrahams Schoß - sicher und geborgen); Christus/ Christi (wie das Leiden Christi aussehen - sehr schlecht, elend aussehen); David (davon singt David nicht! - Ausdruck der Ablehnung); Hiob (arm wie Hiob - sehr arm); Josef (den heiligen Josef spielen - geschlechtlich enthaltsam leben); Judas (falsch wie Judas sein; den armen Judas singen müssen - in einen Zustand geraten, in dem man Klagelieder anstimmt); Lazarus (armer Lazarus ein bedauernswerter Kranker), Petrus (sich mit Petrus bekanntmachen - sterben); Saulus/Paulus (aus einem Saulus zu einem Paulus werden aus einem Gegner einer Sache zu deren eifrigen Befürworten werden); персонажами та атрибутами міфів: Amor (von Amors Pfeil getroffen seinsich verliebt haben); Argus (mit Argusaugen über etwas wachen - scharf / misstrauisch auf etwas achten; wachsam sein); (den gordischen Knoten durchhauen - ein Problem mit einem Schlage lösen); Morpheu (in Morpheus' Armen ruhen / liegen schlafen); Pegasus (den Pegasus besteigen / reiten dichten, reimen); Tantalus (Tantalusqualen / Tantalosqualen erleiden - Schmerzen / Angst erleiden müssen); Achilles (die Achillesferse seinder wunde Punkt sein); Damokles (über jemandem hängt / schwebt ein Damoklesschwert - jemand ist einer ständigen Bedrohung ).

Мотиваторами фразеологізмів можуть бути також німецькі національні імена: Otto, August, Michael, Fritz, Heinrich, Hans (ein dummer August; etwas für den alten Fritzen tun; was Großhans sündigt, muss Kleinhans büßen; den müden Heinrich spielen; j-n zum Michael machen); імена відомих особистостей (письменників, винахідників, історичних постатей, науковців): Blücher (Гебгард-Леберехт фон Блюхер був пруським офріцером, який відзначився переможними битвами при Ватерлоо та Лейпцігу; rangehen wie Blücher - eine Sache mutig anpacken); Wilhelm (король Пруссії Фрідріх Вільгельм II відзначився своєю схильністю до розкішного життя; den dicken Wilhelm machen/ markieren - verschwenderisch, großzügig, leben); Willi (Віллі Брандт - німецький та європейський політик, лауреат Нобелівської премії; den starken Willi markieren - sich viel Durchsetzungskraft zutrauen); Johann Wolfgang von Goethe (Йганн Вольфганг фон Гете німецький поет, прозаїк, драматург, мислитель і натураліст вважається засновником сучасної німецької літератури; so was lebt, und Goethe musste sterben - Redewendung angesichts eines dummen Menschen. Solch eine dumme Person ist leider unverwüstlich); Kotzebue (Август фрон Котцебу був німецьким драматургом i письменником; Kotzebues Werke harausgeben sich erbrechen); Xanthippe (Ксантіппа - дружина грецького фрілософра Сократа, яка відома через свій поганий характер; Xanthippen werden noch immer gebohren - die bösen Weiber sterben nie aus). Іноді прецедентне ім'я є недостатнім у своїй вербальній фрормі для репрезентації прецедентної концептуальної структури та редерентної ситуащії. Наприклад, на підставі одного оніму Marie (Pechmarie - Mädchen, dem allen zum Unglück ausschlägt, Marie - Geld, dicke Marie - viel Geld, wohlgefüllte Brieftasche; linke Marie - Falschgeld), ерцгерцогиня Австрії Марія-Терезія, за ім'ям якої було названо талер - срібну вагову монету, може бути сплутана $з$ героїнею твору Людвіга Бехштайна «Goldmarie und Pechmarie». Введення такого імені до тексту потребує уточнення.

Актуалізація прецедентного тексту відбувається шляхом апелящії до топонімів 3 міфологічних, релігійних, літературних сюжетів: (Eulen nach Athen tragen, zwischen Skylla / Scylla und 
Charybdis sein, eine ägyptische Finsternis, Sodom und Gomorra; das Trojanische Pferd, böhmische Dörfer, den Gang nach Canossa antreten (müssen), in Buxtenhude. Не останню роль відіграють історичні події в створенні прецедентного френомену, що нам демонструють такі приклади: (den Rubikon überschreiten - einen entscheidenden Schritt tun, den man nicht mehr rückgängig machen kann; в 49 р. до н. е. Юлій Цезар, порушивши заборону римського сенату, перейшов зі своїми військами річку Рубікон, що відокремлювала Умбрію від Північної Італії, після цього почалася громадянська війна, в ході якої Цезар оволодів Римом); (erschlossen sein wie Robert Blum - am Ende seiner Kräfte, völlig erschöpft sein; таке порівняння відсилає до подій Віденського повстання, в яке потрапив видавець книг з Ляпціга Роберт Блюм, під час якого він був застрелений); назви народів, племен, національностей (hausen wie die Hunnengewalttätig, roh sein, toben, Zerstörungen anrichten; гуни - загальна назва союзу кочових племен, вся Свропа здригалась від їх спустошливих набігів); (wie der ewige Jude sein - immer unterwegs / rastlos sein); (einen Mohren weißwaschen wollen - etwas vergebliches versuchen); (stolz wie ein Spanier sein - sehr stolz sein; гордість вважається однією із особливостей іспанського народу). Прецедентними мотиваторами фразеологізмів слугують назви грошових одиниць (durch Mark und Pfennig gehendurchdringend, erschütternd, grell sein); продуктів харчування (Das geht ja wie das Brezelbacken! das geht sehr gut / schnell / einfach).

У своєму дослідженні проблеми породження прецедентних текстів В.Г. Костомаров зауважує певні закономірності, які сприяють перетворенню фррагментів тексту в прецедентні висловлювання [2, с. 73-76]. В основному, як вважае автор, це можуть бути назви текстів, початок або кінець тексту, речення, які немов акумулюють увесь його зміст. У цьому аспекті як прецедентні тексти у німецькій мові найчастіше знаходять свій вияв твори Е. М. Ремарка «Im Westen nichts Neues», "Drei Kameraden", Г. Гecce "Steppenwolf» та трагедія Й. В. Гете "Faust», "Die Leiden des jungen Werther», зокрема, назва вірша Гайнріха Гайне "Ich weiß nicht, was soll es bedeuten...." та його останній рядок: "Und das hat mit ihrem Singen die Lorelei getan» - ironische od. scherzhafte Anspielung auf die männliche Verführbarkeit. Прикладом може слугувати також назва автобіографої Й. В. Гете «Dichtung und Wahrheit», яка використовуеться як заголовок в статті про технічні та екологічні проблеми, де автори за допомогою методу подвійної актуалізації будують мовну гру на одночасному співставленні семантики обох омонімів Dichtung (поезія) та Dichtung (забезпечення герметичності).

Актуалізація прецедентного тексту, як вже зазначалося вище, може слугувати мотиватором фрразеологічної одиниці в німецькій мові. Як приклад розглянемо казку Братів Грімм «Hans im Glück», назва якої стала мотиватором фрразеологізмів Hans im Glück - unbekümmerter, sorgloser Mensch, або Hans im Glück haben trotz einer schlechten Lage noch Glück haben, da es noch schlimmer hätte passieren können, a також історичний роман Джемса Феннімора Купера «Останній 3 могікан» ( нім. «der letzte
Mohikaner») der letzte Mohikaner - der / die / das allein noch übrig Gebliebene; ein Nachzügler. Maємо підкреслити, що мотиваторами неофразеологізмів в німецькій мови можуть слугувати назви фрільмів, як наприклад, Bonnie und Clyde: Mann und Frau, welche erregende Verbrechen begangen haben, або, наприклад, назва німецького трагікомедійного фрільму «Good Bye, Lenin», яка вживатиметься на позначення прощання 3 проблемами минулого життя. Такі тексти, на наш погляд, можна віднести до універсально-прецедентного типу, оскільки він міститься в універсальній когнітивній базі, що редеруе до загальновідомих ситуащій. Так само Г. Г. Слишкін, 3 огляду на апелювання адресата до відповідних текстів, виокремлює ремінісенції, серед яких, під нагадуванням розуміє пряме відтворення мовної одиниці, яка $€$ іменем певного текстового концепту [6, с. 128]. Послуговуючись термінологією Г. Г. Слишкіна, у процесі проведеного дослідження фрразеологізмів нам вдалося зафріксувати пряме цитування та квазіцитування. Під прямим цитуванням розуміємо дослівне відтворення мовною особистістю в своєму дискурсі частини або всього тексту в такому вигляді, в якому цей текст зберігся в її пам'яті. Однак, маємо зауважити, що 3 часом цитати можуть утвердитися в ментальному лексиконі людей та стати самостійними, у ході якого контекстуально зумовлене значення цитати стає загальновідомим і поступово роль контексту для розуміння фрразеологізму зменшуеться. Фразеологізм seine Hände in Unschuld waschen - це цитата із Біблії, a das ist des Pudels Kern походить із "Фауста" Й. В. Гете, значення таких виразів загальновідоме без контексту згаданих джерел. Під квазіцитуванням розуміемо відтворення всього тексту або його частини 3 певною метою у модифікованому вигляді. Останні два типи прецедентних френоменів, на наш погляд, можна віднести за класифікацією В. В. Красних до прецедентних висловлень. Таке явище яскраво ілюструють фрразеологізми: $a b$ nach Kassel - може вживатися в різних ситуаціях та означати «Schnell fort! Ab ins Bett! Verschwinde! (Забирайся звідси! Іди-но спати! Забирайся геть!). Фразеологізм апелює до подій, які пов'язані з останнім фрранцузьким імператором Наполеоном III, коли його, взятого в полон після поразки в битві під Седаном, везли в місто Кассель, жителі вигукували Наполеону вслід: "Ab nach Kassel!». Безперечно, що оразеологізм Ach du, (mein Sohn) Brutus?- also auch du verrätst mich, lässt mich in Stich? (здивування тим, що хтось перейшов до іншої сторони та кинув Вас) експлікуе прецедентні мотиватори, під якими розуміемо у творі В. Шекспіра «Юлій Цезар» пряме цитування останніх слів Юлія (Et tu, Brute!) перед своєю смертю.

Обгрунтовуючи статус прецедентних френоменів як складників концептуальної системи, зауважимо, що у когнітивному аспекті за прецедентними мотиваторами завжди стоїть певна структура знань, фррагменти якої корелюють зі складниками структури знань про позначене. Прецедентна мотивація фрразеологічних одиниць відповідно до параметру статусу мотиватора певного компонента структури знань може бути кваліфрікована в нашому дослідженні як пропозиційна, асоціативно-термінальна та модусна, 
а також грунтуватися на міфрологічній природі френоменів. Приміром, якщо прецедентний мотиватор в ономасіологічній структурі фрразеологізму виправданий редеренційно і є складником предикатно-аргументних структур, як нам це демонструють dpразеологізми: in Buxtenhude; das geht wie Brezelbacken; rangehen wie Blücher; seinen Kaiser Wilhelm unter etwas setzen; den starken Willi markieren. Приналежність прецедентного мотиватора до асоціативно-термінальної структури знань спостерігаємо у таких фрразеологізмах як der letzte Mohikaner, den Rubikon überschreiten, linke Marie. Модусний тип перецедентної мотивації стосуеться майже всіх їі типів, адже оцінку вважають універсальною лінгвістичною категорією, яка переважно закладена у значенні фрра- зелогізмів. Дуже велика кількість прецедентно мотивованих фрразеологізмів грунтуються на міфологічній природі, яка фрормує норми та цінності етнічного суспільства та $є$ потужним регулятором процесу культурної та етнічної ідентифрікації.

Висновки 3 даного дослідження i перспективи. Підводячи підсумки, зазначаємо, що знаки прецедентних френоменів є активними в номінативних процесах фрразеологізмів. Звернення до них можливе через прецедентні тексти, імена та висловлення, які стають їхніми символами та слугують засобами збереження й трансляції культури народу. Перспективи дослідження полягають в окресленні меж прецедентних френоменів та в з'ясуванні специфіки невербальних прецедентних френоменів.

\section{Список літератури:}

1. Караулов Н.Ю. Русский язык и языковая личность. Москва : Наука, 1987. 263 с.

2. Костомаров В.Г., Бурвикова Н.Д. Как тексты становятся прецедентными. Русский язык за рубежол. 1994. № 1. C. 73-76.

3. Красных В.В. Этнопсихолингвистика и лингвокульторология : курс лекций. Москва : ИТДГК Гнозис, 2002.284 с.

4. Селіванова О.О. Світ свідомості в мові. Монографічне видання. Черкаси : Ю. Чабаненко, 2012. 488 с.

5. Селіванова О.О. Лінгвістична енциклопедія. Полтава : Довкілля-К, 2010. 844 с.

6. Слышкин Г.Г. От текста к символу: лингвокультурные концепты прецедентных текстов в сознании и дискурсе. Москва : Academia, 2000. 128 с.

\section{References:}

1. Karaulov N.Yu. (1987). Russkij yazyk i yazykovaya lichnost [The Russian Language and the Linguistic Personality]. Moskva: Nauka. (in Russian)

2. Kostomarov V.G., Burvikova N.D. (1994). Kak teksty stanovyatsya preczedentnymi [How the Texts Become the Precedent Ones]. Russkij yazyk za rubezhom, no. 1, pp. 73-76.

3. Krasnykh V.V. (2002). Etnopsikholingvistika $i$ lingvokultorologiya: kurs lekczij [Ethnopsycholinguistics and Linguoculturology: Lectures]. Moskva: ITDGK Gnozis. (in Russian)

4. Selivanova O.O. (2010). Linhvistychna entsyklopediia [Linguistic Encyclopedia]. Poltava: Dovkillia-K. (in Ukrainian)

5. Selivanova O.O. (2012). Svit suidomosti v movi. Monohrafichne vydannia [The World of Consciousness in the Language. Monographic Edition]. Cherkasy: Yu. Chabanenko. (in Ukrainian)

6. Slyshkin G.G. (2000). Ot teksta $k$ simvolu: lingvokulturnye konczepty preczedentnykh tekstov $v$ soznanii $i$ diskurse [From the Text to the Symbol: Linguistic and Cultural Concepts of the Precedent Texts in Consciousness and Discourse]. Moskva: Academia. (in Russian) 